\title{
16. GEOCHEMICAL ANALYSES OF POTENTIAL PETROLEUM SOURCE BEDS
}

\author{
Paul J. Cernock, Texaco Inc., New Orleans, Louisiana
}

\section{INTRODUCTION}

Of the eight sites drilled during Leg 24, only one provided a cored interval which was visually definable as a potential petroleum source bed. The lithologic description for Site 231 shows two thin layers (upper Miocene age) at $89-91 \mathrm{~cm}$ and $103-105 \mathrm{~cm}$ in Core 44 , Section 1 as bitumen streaks containing approximately $5 \%$ bitumen. Three samples (Table 1) were sealed in plastic bags and later geochemically analyzed for organic content and heavy hydrocarbons by a commercial laboratory. ${ }^{1}$ Light hydrocarbon analyses, i.e., $\mathrm{C}_{1}$ through $\mathrm{C}_{7}$, were not performed because of the sampling procedure. The samples were sealed without benefit of distilled water and bactericide; therefore, bacterial action upon the light hydrocarbons precluded their measurement. Likewise, the plastic bag offered an escape route for the light volatile hydrocarbons.

TABLE 1

Sample Identification, Site 231

\begin{tabular}{lccc}
\hline & \multicolumn{3}{c}{ Sample Identification } \\
\cline { 2 - 4 } Sample & Core & Section & $\begin{array}{c}\text { Sample Depth } \\
\text { (cm) }\end{array}$ \\
\hline 1 & 44 & 1 & $89-91$ \\
$2(\mathrm{dk})$ & 44 & 1 & $103-105$ \\
$3(\mathrm{lt})$ & 44 & 1 & $103-105$ \\
\hline
\end{tabular}

The geochemical analyses carried out comprised the standard percent organic carbon (Table 2); total $\mathrm{C}_{15+}$ soxhlet extraction, deasphalting, and liquid chromatographic separation (Table 3 ); $\mathrm{C}_{15}+$ normal paraffin analysis by gas chromatography (Table 4 , Figure 3 ); and visual kerogen assessment (Table 5).

Before progressing into the specifics of this study, it is appropriate to present a very simplified scheme of sequence for hydrocarbon genesis. The top diagram in Figure 1 illustrates the development of hydrocarbons produced by the progressive thermal degradation of organic matter, which is finely disseminated throughout the source rocks and/or sediments. An envelope of interest is defined between geothermal gradients of $3^{\circ} \mathrm{F} / 100$ feet and $1^{\circ} \mathrm{F} / 100$ feet, which represent the range of most geothermal gradients in the world. Initial thermal degradation of organic matter originally produces primarily a heavy oil. Continued thermal degradation produces oil and gas, light oil and gas, and finally the end product of pyrolysis-only dry methane gas (Klemme, 1972).

\footnotetext{
${ }^{1}$ GeoChem Laboratories, Inc., Houston, Texas .
}

The bottom diagram in Figure 1 is a general illustration of the synthesis of hydrocarbons by bacterial activity. There is no evidence for the generation of oil as such by biochemical processes, although certain hydrocarbons are produced metabolically by numerous organisms (Stevens, 1956). Fermentation of plant debris yields abundant quantities of methane, which is the source of marsh gas. Minute quantities of ethane are also produced in this manner. The aerobic and anaerobic bacterial action is limited to temperatures generally less than $212^{\circ} \mathrm{F}$. However, literature shows that bacterial action predominates at shallow depths and becomes insignificant with increasing depth (depicted by the width of the arrows in the bottom diagram of Figure 1). Biogenically-derived methane gas would be produced mainly at depths less than a couple of thousand feet.

This study is oriented primarily toward defining the character of potential liquid petroleum source beds - since this is a thermal process. The degree of maturation of a potential source bed herein will be defined by its normal paraffin distribution, pristane/phytane ratio, saturate/ atomatic ratio, and kerogen analysis.

\section{NORMAL PARAFFIN DISTRIBUTION AND PRISTANE/PHYTANE RATIO}

Figure 2 presents a chromatogram of the $C_{15}+$ paraffinnaphthene fractions of a typical immature shale. The insert "A" illustrates the method of determining the peak heights of the normal paraffins. The chart at the Top of Figure 2 demonstrates the calculation of the average ratio of odd-to even-numbered $n$-paraffins (CP index). Two different denominators are used $\left(\mathrm{C}_{26}-\mathrm{C}_{32}\right.$ and $\left.\mathrm{C}_{24}-\mathrm{C}_{30}\right)$ so as not to preference the ratio to the higher or lower even-numbered $n$ - paraffins. The CP index of 3.12 identified a typical immature shale.

Studies presented in the literature show that recent and immature sediments have high values of $\mathrm{CP}$ index, ranging from 2.5 to 5.5 with an overall average of 3.6 . These high values are due to the contribution of land derived organic matter. The CP index approaches 1.0 with increasing maturity (Bray and Evans, 1961). A low CP index may also occur if the organic matter is purely marine in origin, such as phytoplankton.

The pristane/phytane ratio of 0.63 in Figure 2 indicates immaturity. This ratio becomes much greater than 1.0 with increasing maturity.

The $C_{15}$ + paraffin-naphthene analyses by gas chromatography for the three sediment samples are presented in Table 4 and Figure 3 . The gas chromatographic patterns (Figure 3 ) clearly show that Samples 2 and 3 are closely 
TABLE 2

Geochemical Analytical Data

\begin{tabular}{ccccccc}
\hline Sample & $\begin{array}{c}\text { Sample } \\
\text { Depth } \\
(\mathrm{cm})\end{array}$ & $\begin{array}{c}\text { Organic } \\
\text { Carbon } \\
\text { Content }\end{array}$ & $\begin{array}{c}\text { Total } \\
\mathrm{C}_{15}+\text { Extract } \\
(\mathrm{ppm})\end{array}$ & $\begin{array}{c}\text { Total } \\
\mathrm{HC} \text { 's } \\
(\mathrm{ppm})\end{array}$ & \multicolumn{2}{c}{ Kerogen Data } \\
\cline { 6 - 8 } & & & & & Type & Alteration \\
\hline 2 & $89-91$ & 1.65 & 5544 & 300 & Am, H, W & 1 \\
3 & $103-105$ & $1.83,1.84$ & 3930 & 350 & Am, H, W & $1-1+$ \\
\hline
\end{tabular}

TABLE 3

Summary of $\mathrm{C}_{15}+$ Soxhlet Extraction Deasphaltening, and Liquid Chromatography

\begin{tabular}{|c|c|c|c|c|c|c|c|c|c|}
\hline \multicolumn{10}{|c|}{ Concentration of Extracted Materials in Rock } \\
\hline \multirow[b]{2}{*}{ Sample } & \multirow{2}{*}{$\begin{array}{c}\text { Total } \\
\text { Extract } \\
\text { (ppm) }\end{array}$} & \multirow[b]{2}{*}{$\begin{array}{l}P-N \\
(p p m)\end{array}$} & \multirow[b]{2}{*}{$\begin{array}{c}\text { AROM } \\
(\mathrm{ppm})\end{array}$} & \multicolumn{2}{|c|}{ Hydrocarbons } & \multicolumn{2}{|c|}{ Nonhydrocarbons } & \multirow[b]{2}{*}{$\begin{array}{c}\text { Noneluted } \\
\text { NSO's }\end{array}$} & \multirow[b]{2}{*}{$\begin{array}{l}\text { Total } \\
(\mathrm{ppm})\end{array}$} \\
\hline & & & & $\begin{array}{r}\text { Total } \\
\text { (ppm) }\end{array}$ & $\begin{array}{l}\text { Preci } \\
\text { Asph }\end{array}$ & $\begin{array}{l}\text { itated } \\
\text { altene }\end{array}$ & $\begin{array}{l}\text { ted } \\
\text { O's }\end{array}$ & & \\
\hline 1 & 5544 & 155 & 144 & 300 & & 66 & & 44 & 5244 \\
\hline 2 & 3930 & 190 & 160 & 350 & & 00 & & 120 & 3580 \\
\hline 3 & 3709 & 118 & 53 & 172 & & 72 & & 43 & 3537 \\
\hline \multicolumn{10}{|c|}{ Composition of Extracts } \\
\hline Sample & $\begin{array}{c}P-N \\
(\%)\end{array}$ & $\begin{array}{c}\text { Hydro- } \\
\text { carbons } \\
\text { AROM } \\
(\%)\end{array}$ & $\begin{array}{c}\text { PN/ } \\
\text { AROM }\end{array}$ & $\begin{array}{l}\text { Eluted } \\
\text { NSO's }\end{array}$ & $\begin{array}{l}\text { Noneluted } \\
\text { NSO's }\end{array}$ & $\begin{array}{l}\text { Precipitated } \\
\text { Asphaltene }\end{array}$ & $\begin{array}{l}\text { Asph } \\
\text { NSO }\end{array}$ & $\begin{array}{l}\text { HC's } \\
(\%)\end{array}$ & $\mathrm{NC} /$ non-HC \\
\hline 1 & 2.81 & 2.60 & 1.08 & 11.4 & 0.80 & 82.4 & 6.74 & 5.41 & 0.057 \\
\hline 2 & 4.83 & 4.07 & 1.19 & 11.7 & 3.05 & 76.3 & 5.17 & 8.91 & 0.098 \\
\hline 3 & 3.19 & 1.45 & 2.20 & 8.7 & 1.16 & 85.5 & 8.63 & 4.64 & 0.049 \\
\hline
\end{tabular}

TABLE 4

Saturate Hydrocarbon Analyses Normalized Paraffin Distribution

\begin{tabular}{|c|c|c|c|}
\hline Hydrocarbons & Sample 1 & Sample 2 & Sample 3 \\
\hline$n \mathrm{C}_{15}$ & 0.8 & 0.9 & 0.5 \\
\hline$n \mathrm{C}_{16}$ & 1.6 & 1.4 & 0.9 \\
\hline$n \mathrm{C}_{17}$ & 2.8 & 4.8 & 3.3 \\
\hline$i \mathrm{p}-\mathrm{C}_{19}$ & 2.4 & 3.6 & 2.0 \\
\hline$n \mathrm{C}_{18}$ & 5.5 & 8.1 & 7.5 \\
\hline$i \mathrm{p}-\mathrm{C}_{20}$ & 4.3 & 7.8 & 5.2 \\
\hline$n \mathrm{C}_{19}$ & 4.4 & 6.3 & 7.0 \\
\hline$n \mathrm{C}_{20}$ & 5.3 & 6.6 & 6.2 \\
\hline$n \mathrm{C}_{21}$ & 7.9 & 7.1 & 7.0 \\
\hline$n \mathrm{C}_{22}$ & 13.3 & 10.1 & 10.4 \\
\hline$n \mathrm{C}_{23}$ & 15.6 & 9.5 & 10.9 \\
\hline$n \mathrm{C}_{24}$ & 11.2 & 6.8 & 7.3 \\
\hline$n \mathrm{C}_{25}$ & 5.9 & 5.8 & 6.5 \\
\hline$n \mathrm{C}_{26}$ & 5.1 & 5.2 & 4.7 \\
\hline$n \mathrm{C}_{27}$ & 5.1 & 5.6 & 6.3 \\
\hline$n \mathrm{C}_{28}$ & 1.7 & 1.6 & 2.3 \\
\hline$n \mathrm{C}_{29}$ & 3.3 & 4.0 & 4.9 \\
\hline$n \mathrm{C}_{30}$ & 1.2 & 1.2 & 1.5 \\
\hline$n \mathrm{C}_{31}$ & 2.3 & 3.0 & 4.5 \\
\hline$n \mathrm{C}_{32}$ & 0.3 & 0.3 & 0.4 \\
\hline$n \mathrm{C}_{33}$ & 0.2 & 0.3 & 0.9 \\
\hline \multicolumn{4}{|c|}{ Paraffin Distribution (percent) } \\
\hline Paraffin & 14.0 & 8.6 & 9.5 \\
\hline Isoprenoid & 1.0 & 1.1 & 0.7 \\
\hline Naphthene & 85.0 & 90.3 & 89.8 \\
\hline $\mathrm{CP}$ index & 1.44 & 1.75 & 1.95 \\
\hline \multicolumn{4}{|c|}{ Pristane/Phytane ratio } \\
\hline
\end{tabular}

similar, but that Sample 1 differs in the paraffin distribution. There is a very definite preference for $n$-paraffins with odd numbers of carbon atoms in the higher $\left(\mathrm{C}_{24+}\right)$ molecular weight paraffins for all three samples. "The $\mathrm{CP}$ index for the three samples ranges from 1.44 to 1.95. Normally, this might be interpreted as due to differences in maturity; however, all three samples are so close in the stratigraphic column that they could not have been exposed to any significant differences in temperature. Consequently, the differences in $\mathrm{CP}$ index are more likely due to different contributions of land and marine derived organic matter. Another possible, although less understood factor, is microbial reworking at the time of sedimentation. This has a tendency to depress $\mathrm{CP}$ indices. The low values of the pristane/phytane ratio $(0.39-0.57)$ suggest that the sediment is rather immature".

The samples all contain predominant amounts of naphthene components as evidenced by the naphthene envelope (Figure 1) and the computed compositional data (Table 4).

It is interesting to compare the $\mathrm{C}_{15}+$ paraffin-naphthene data of the sediment samples with that from a mature oil of Tertiary age (Figure 4). Surprisingly, the chromatograms are very similar in distribution of naphthenes and comparable in $n$-paraffin content. The pristane/phytane ratio of 1.30 and $\mathrm{CP}$ index of 1.13 both identify this oil as being mature. The author believes that the organic shales from Site 231 will, under increased thermal maturation, produce an oil similar to that in Figure 4.

\section{SATURATE/AROMATIC RATIOS}

The saturate/aromatic ratio and the quantity of total extracted hydrocarbons provide a clue to the maturity of a 
TABLE 5

Visual Kerogen Assessment Data

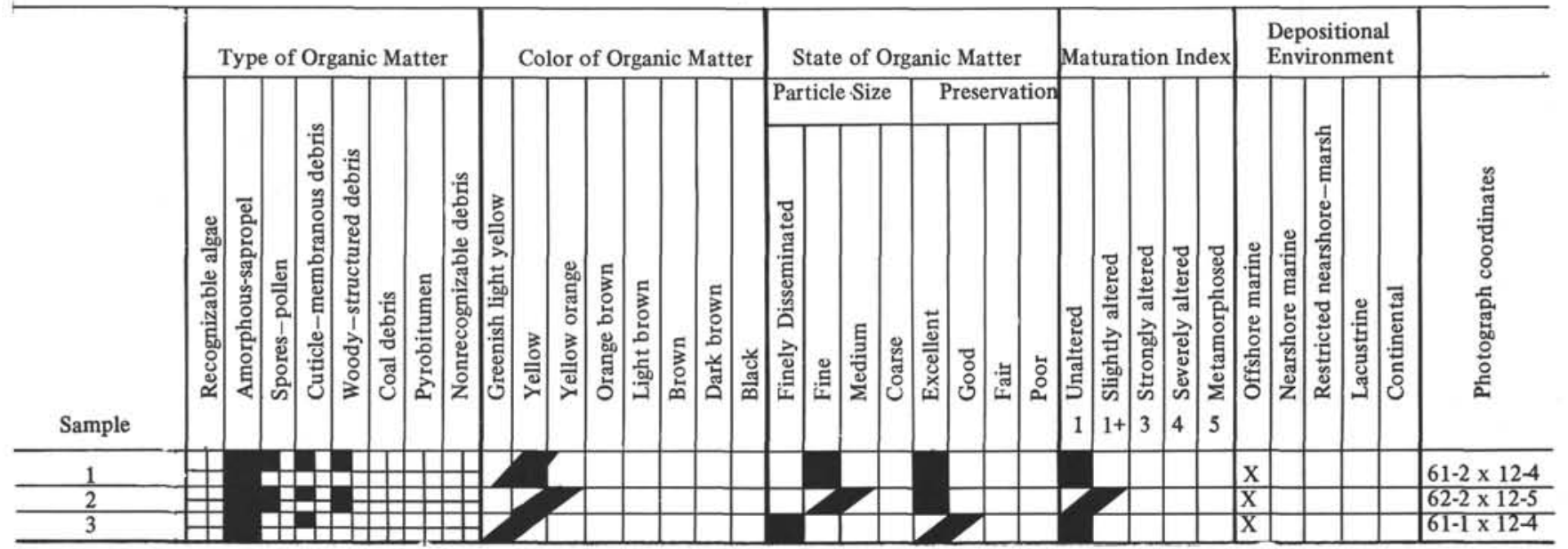

potential source rock. The interpretation of the data presented herein can best be understood when one examines what should occur in an advanced mature section. Such a section would contain a large quantity of extracted hydrocarbons making up the total extract, and the percentage of aromatics would be decreased in favor of an increase in saturates (paraffin-naphthene fraction). The latter is obtained by the thermal degradation of the heavier aromatics yielding the lighter naphthenes and paraffins.

Note that the saturate/aromatic ratio is moderately mature (Table 3, 1.08 to 2.20) suggesting a preference for the saturates. However, the total extracted hydrocarbons only constitute $4.64 \%$ to $8.91 \%$ of the total extract (Table $3)$, suggesting immaturity.

\section{ORGANIC CARBON CONTENT AND KEROGEN ANALYSIS}

All three samples have quite high organic carbon content (Table $2,0.97 \%$ to $1.87 \%$ ) with comparably high total extractable bitumen (Table.2, 3709-5544 ppm). Since moderate source rocks contain approximately $1.0 \%$ organic carbon content, these samples may be rated as good potential source sediments.

The visual kerogen analyses are presented in Table 5. The kerogen is very typical of deep-water sediments being amorphous-sapropel in type and being generally finely disseminated throughout the sample. This organic matter is probably derived exclusively from the water column and represents zoo- and phytoplanktonic debris. Some secondary herbaceous plant and woody debris is also present in Samples 1 and 2.

The maturity of the kerogen is defined by the color and maturation index. The color range of the kerogen was obtained by microscopically examining primarily the plant cuticles in each sample. The scale denotes immaturity to the left (light greenish-yellow) and maximum maturity to the right (black). The maturation index is also obtained by microscopically examining the kerogen. This empirical index is based on color, on visual interpretation of alteration, and by experience in examining numerous samples, ranging from recent "immature" sediments to ancient "mature" known source rocks. Both parameters suggest that the kerogen is totally immature in these sediments. This would suggest that the paraffin-naphthene hydrocarbons previously mentioned are probably primarily indigenous naturally occurring types. The fact that the total hydrocarbons only constitute $4.64 \%$ to $8.91 \%$ of the total extract further attests to this interpretation.

\section{CONCLUSIONS}

The upper Miocene age bitumen layers at Site 231 are defined as being immature source beds. However, with continued thermal degradation, they would be good potential petroleum source beds. The product of pyrolysis would probably be a mature, predominantly naphthenic oil, similar to that shown in Figure 4.

The significance of this short study is that moderately rich potential petroleum source sediments are present in deep-water sediments. With similar thicker layers present and in proximity to coarse-grained turbidites acting as potential reservoirs, the prospectiveness for plays in deepwater environments is greatly enhanced.

\section{REFERENCES}

Bray, E. E. and Evans, E. D., 1961. Distribution of $n$-paraffins as a clue to recognition of source beds: Geochim. Cosmochim. Acta, v. 22, p. 2-15.

Klemme, H. D., 1972. Heat influences size of oil giants: Oil Gas J., July 17, p. 136-144.

Stevens, N. P., 1956. Origin of petroleum-A review: Am. Assoc. Petrol. Geol. Bull., v. 40, p. 51-61. 


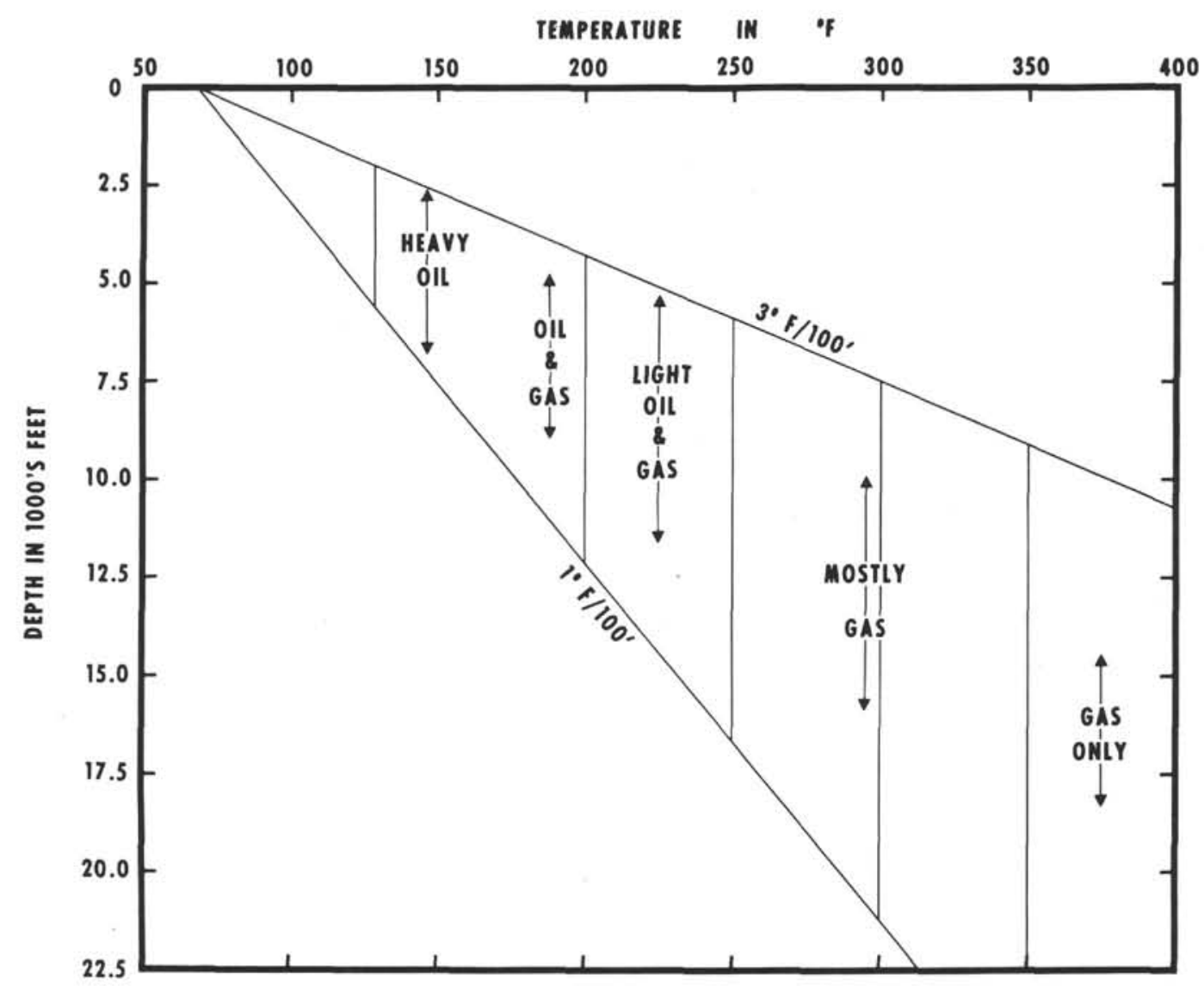

HYDROCARBONS PRODUCED BY THERMAL DISINTEGRATION

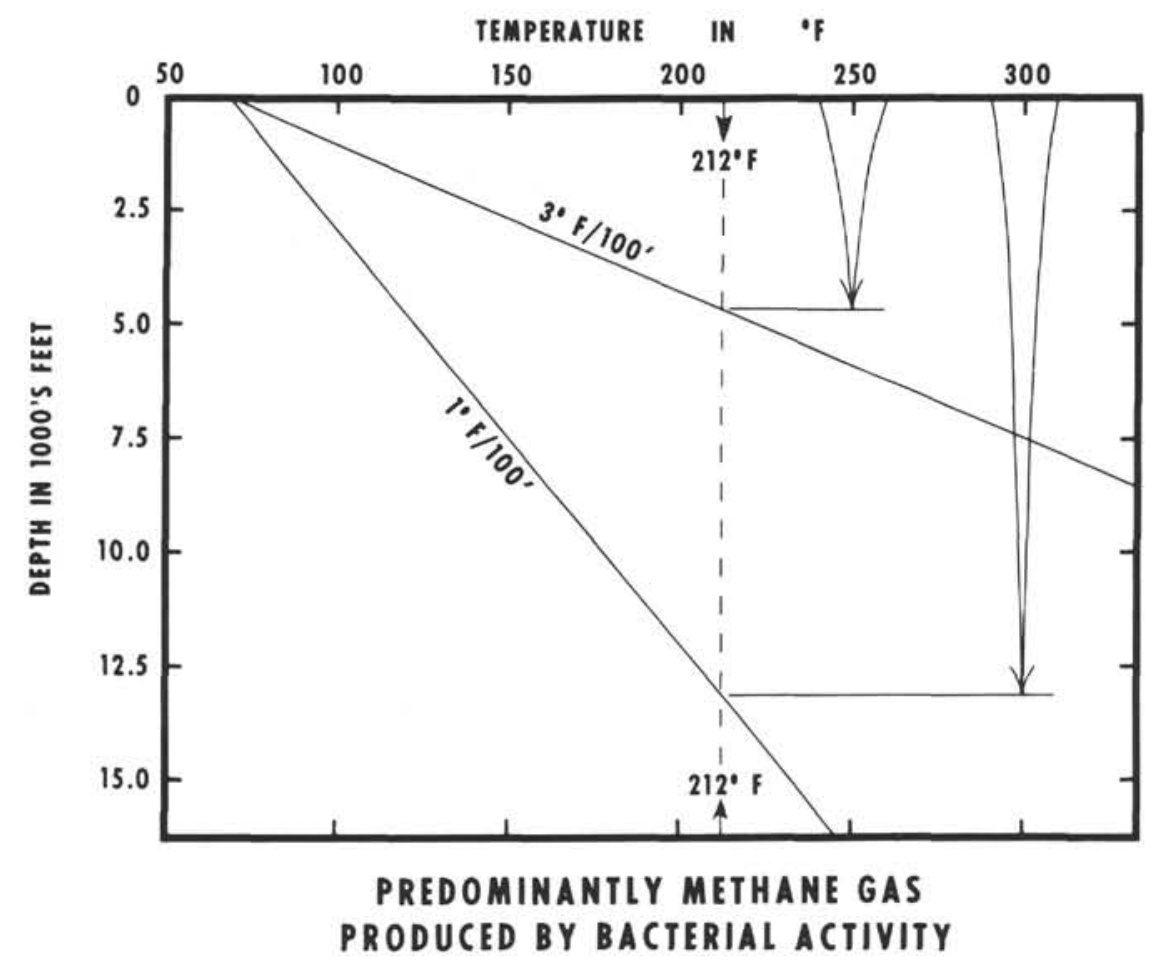

Figure 1. Generalized illustrations showing depth/temperature relation for hydrocarbon genesis. Hydrocarbons produced by thermal disintegration (top); predominantly methane gas produced by bacterial activity (bottom). 


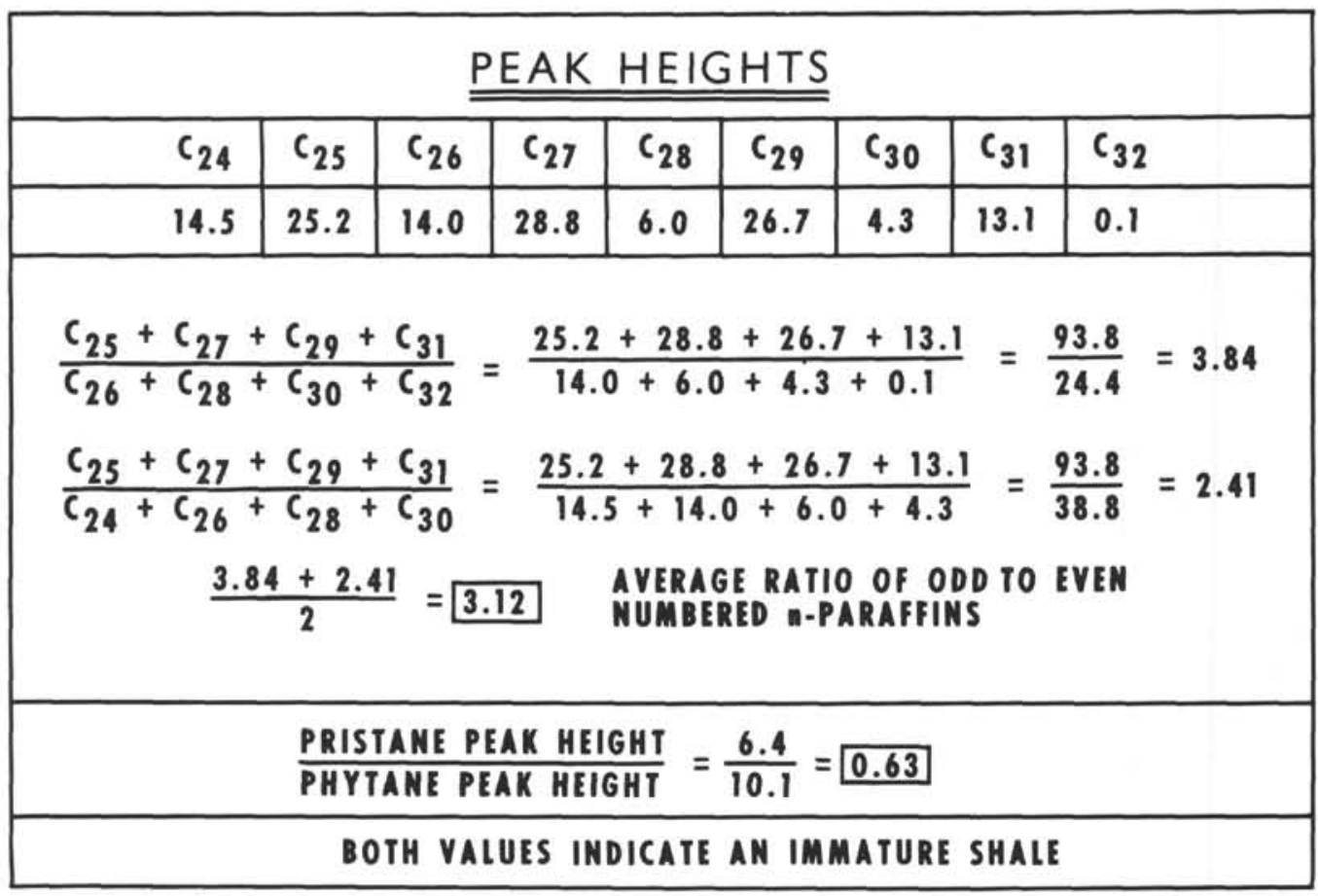

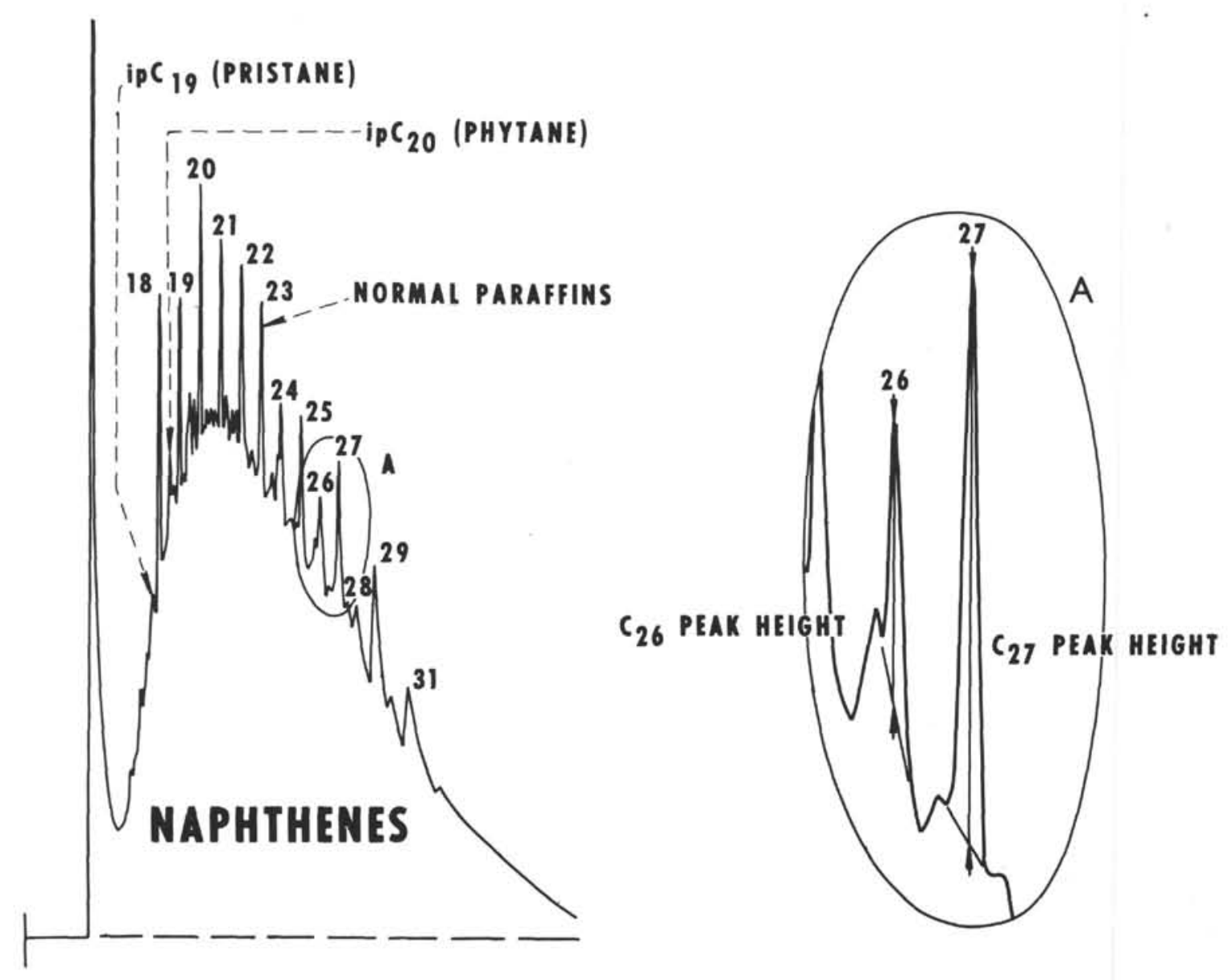

Figure 2. Chromatogram of $C_{15^{+}}$paraffin-naphthene hydrocarbon fractions for an immature shale. 

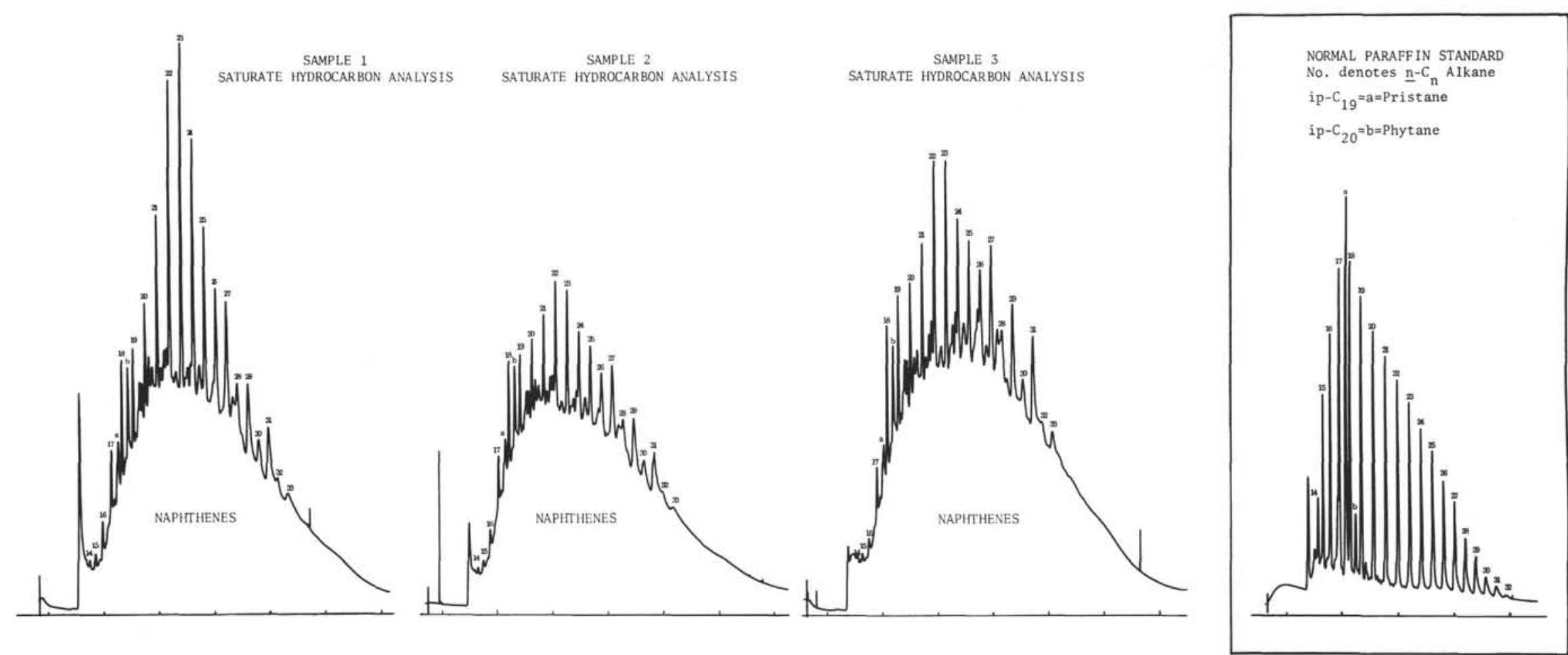

Figure 3. Chromatograms of $C_{15}+$ paraffin-naphthene hydrocarbon fractions for three sediment samples from Section 1, Core 44 of Site 231. 


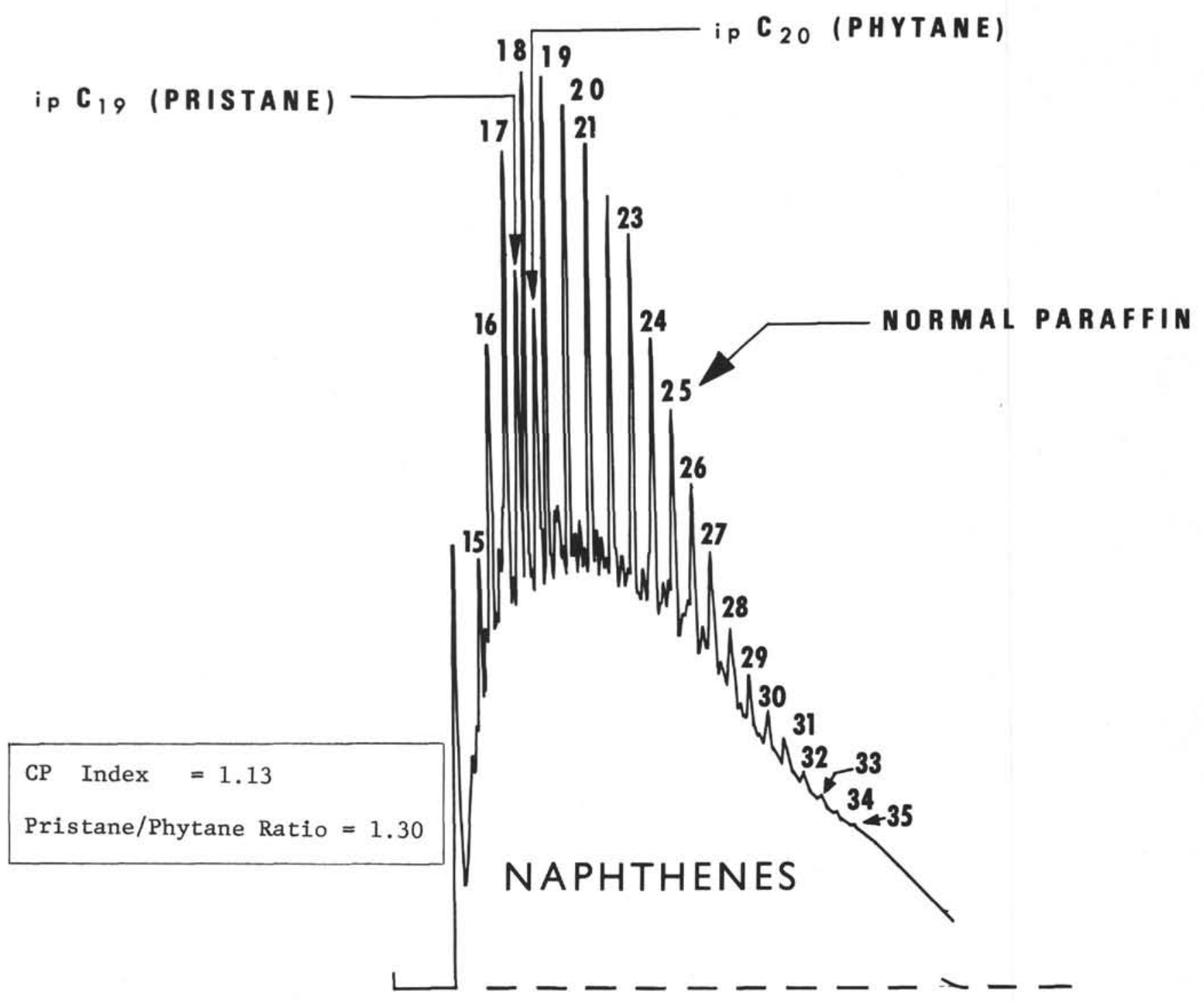

Figure 4. Chromatograms of $C_{15}+$ paraffin-naphthene hydrocarbon fractions for a mature oil of Tertiary age. 